SENKA ŠEKULARAC-IVOŠEVIĆ, Ph.D. ${ }^{1}$

(Corresponding author)

E-mail: senkas@ucg.ac.me

MELIKA HUSIĆ-MEHMEDOVIĆ, Ph.D. ${ }^{2}$

E-mail: melika.husic@efsa.unsa.ba

ELEN TWRDY, Ph.D. ${ }^{3}$

E-mail: elen.twrdy@fpp.uni-lj.si

1 University of Montenegro

Faculty of Maritime Studies Kotor

Dobrota 36, 85330 Kotor, Montenegro

2 School of Economics and Business in Sarajevo

Trg oslobođenja - Alija Izetbegović 1, 71000 Sarajevo,

Bosnia and Herzegovina

3 University of Ljubljana

Faculty of Maritime Studies and Transport

Pot pomorščakov 4, 6320 Portorož, Slovenia
Traffic Management

Preliminary Communication

Submitted: 14 Jan. 2018

Accepted: 24 Oct. 2018

\title{
REPOSITIONING STRATEGY IN THE MARITIME PORT BUSINESS: A CASE STUDY FROM MONTENEGRO, PORT OF ADRIA
}

\begin{abstract}
The main objective of this paper is to define the repositioning strategy of the Port of Adria, which is the leading container maritime port of Montenegro. The strategy is an integral reflection of the analysis of internal (competitive advantage and financial strength) and external (the potential of container maritime port industry and environmental stability) repositioning criteria. The case study in this paper is mainly accomplished through the definition of specific propositions that clarify the connections between these criteria and the repositioning strategy. Knowledge and attitudes of stakeholders are used with the purpose of modeling a marketing strategy, which is based on an inductive study. The paper proposes a model based on a specific maritime port case which can be applied to any other case of maritime port repositioning as well.
\end{abstract}

\section{KEY WORDS}

maritime port repositioning; financial and environmental stability; competitive advantage; container industry; SPACE matrix;

\section{INTRODUCTION}

There are many continuous and often very radical changes occurring today in the maritime port service market, while port competition is severe, and customers are demanding. Therefore, when it is notable that the market share and total cargo throughput of a maritime port are significantly reduced, it is necessary to analyze the current market position and the possibility of repositioning.
The contemporary maritime port business environment is under a considerable influence of the numerous factors of the so-called "new economy", i.e., the informative, digital network or the knowledge economy in the conditions of a "hypercompetitive environment" [1]. Hence, if a maritime port develops a competitive advantage, then its business operations require a new approach based on the marketing concept. Namely, the application of a customer-centric approach indicates the introduction of a modern maritime port generation, i.e., a customer-centric community-focused maritime port [2].

From the strategic marketing perspective, maritime ports aim to achieve a leading position on the target market and many of them have a natural predisposition to accomplish this due to their favorable geographical location [3]. However, in order to foresee this vision, it is more important to implement a clearly defined marketing strategy in the target market. Therefore, the strategy must be consistent with the objectives, internal resources (capacity) and opportunities within the target market where a maritime port strives to achieve a dominant, strong, favorable, sustainable and/or simply different place among the competition [4]. This strategy involves a whole range of complementary marketing strategies, i.e., market segmentation, targeting, differentiation and/or the (re)positioning of maritime ports [5]. For a successful market position, which is the aim of every maritime port, the so-called 3R strategy, i.e., rebranding, restructuring and repositioning, should be implemented [6]. 
This paper focuses on the complex repositioning strategy of maritime ports. There are clear customer perceptions of the market positions of competing maritime ports, but new and more attractive positions require significant financial, marketing and time resources. Additionally, inadequate repositioning may weaken the existing position and put at risk the overall image of a maritime port in the market. There are continuous organizational changes, as well as many exogenous factors (economics and politics) that could influence the operations of a maritime port. The aforementioned makes the process of repositioning more complex. Therefore, in accordance with the related literature, the research question proposed in this paper is: how do maritime ports define the optimal repositioning strategy in the highly competitive maritime port industry?

The purpose of this paper is to propose a model for defining the optimal strategy of maritime port repositioning by using an inductive method based on the case study of the Montenegrin Port of Adria (hereinafter: the Port). Furthermore, this paper aims to provide a framework for upgrading an already initiated process of improving the current market position of the Port as well as provide guidance for the application of possible marketing interventions. Considering the contemporary functioning of the Port, a description of the repositioning phenomenon will be based on a variety of data sources.

This Port is a perfect example of a process of maritime port reorganization because of its long tradition (it was established as the Port of Bar in 1906) [7]. In 2013, Global Ports Holding, a port group and operator in the Mediterranean and Asia-Pacific markets, entered the ownership structure as a strategic partner with a concession for 30 years, acquiring the majority of the shares in the Port [8]. In July 2015, the new brand name Port of Adria was adopted along with a modern visual identity.
The Port operates in an extremely competitive environment created by other Adriatic, Aegean and Black Sea maritime ports. In 2016, the total container throughput of the Port was $41,828 \mathrm{TEU}$, which is far lower than the throughput of the competing maritime ports such as Koper (844,758 TEU), Rijeka $(137,150$ TEU), Piraeus Container Terminal (3,450,000 TEU) and Constanta (711,339 TEU) (according to the ports' websites). Container throughput of the selected Adriatic maritime ports is given in Figure 1. The mentioned maritime ports have better business results because they have entered the repositioning process earlier, e.g. the Port of Rijeka in 2001. Therefore, the Port examined in this paper is a solid example of how the issue of repositioning is crucial for achieving competitive market positions.

Assuming that the goal of further development is to elevate the Port in this highly competitive market, its management has to specify a strategy for the repositioning of the Port $[9,10]$.

In this article, based on the case study methodology [11-14], we have created the propositions for the research question, defined and analyzed the case of the Port, thus trying to build a model relevant for further maritime port repositioning strategy.

\section{LITERATURE REVIEW}

Repositioning may be defined as a conscious act undertaken by companies as they adapt to a changing commercial environment [15]. This actually means that repositioning occurs as a need when there is an obvious gap between the needs of the market and the capabilities of a company [16]. In spite of the significant body of knowledge on repositioning strategies, the existing theoretical models and practical examples do not adequately answer the question of how maritime ports consider market repositioning. On the contrary, there is a body of knowledge that analyses the marketing aspects of the business operations of maritime ports (competitiveness, positioning, marketing

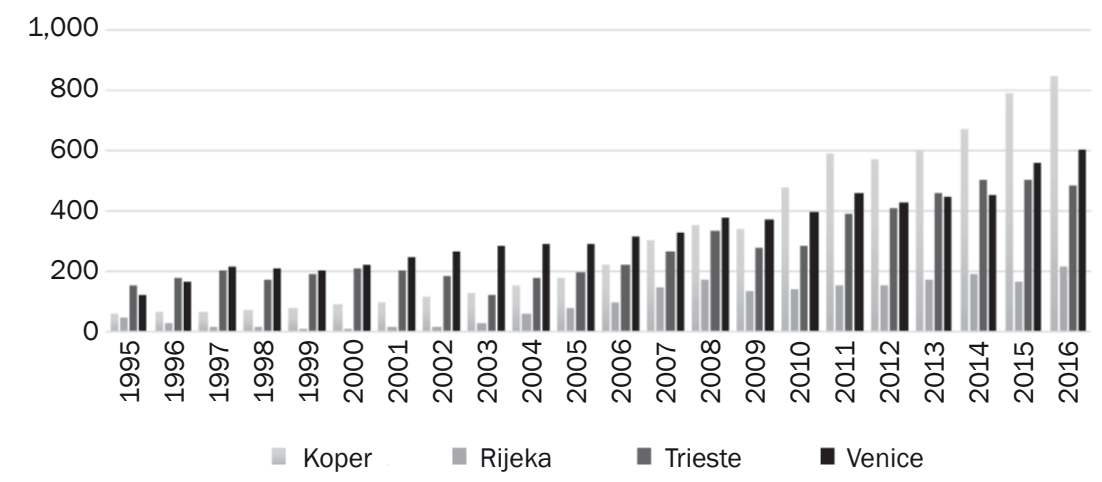

Figure 1 - Container throughput of the selected Adriatic maritime ports (in 1,000 TEU) Source: Authors according to ports' websites 
mix, etc.), while the literature and theoretical models regarding the strategy of repositioning are at an infancy phase.

Constant monitoring of the positions of maritime ports in perceptual maps is the ground floor for making decisions on repositioning $[17,10]$. Recent literature does not cover maritime ports as a business per se, their repositioning strategies included. There has always been a management dilemma about the type of repositioning appropriate for a specific maritime port. There are three main repositioning strategies to be distinguished: zero, gradual and radical re positioning [16]. Zero repositioning is focused on the original target segment and competitive advantage. The second type of repositioning is a small, gradual and natural evolution into new products/services and higher assortments or new methods of presentation, while the third type of repositioning is radical and includes a shift into the new types of business operations, products/services or a total re-presentation of the company [16]. In addition, when there is a need for repositioning, the organization has to define a specific approach to repositioning based on the Ansoff Matrix [18]: a) the repositioning of a product (different product/same target market); b) the repositioning of an image (same product/same target market); c) intangible repositioning (same product/different target market); or d) tangible repositioning (different product/different target market). In this paper, we have followed the abovementioned premises.

Considering that there is a significant difference between corporate repositioning and brand repositioning [19], special attention should be given to corporate repositioning which is more complex and has a strategic character. This research is a way of extending classic marketing strategy along with additional qualities to explicate the complex financial, competitive, environmental and industrial factors based on qualitative and quantitative data and to estimate the influence of these factors on the business operations of modern maritime ports. Therefore, the need for an inductive study has emerged [11]. Multiple-case studies typically provide a stronger base for research [20], but in this paper we were able to expressively describe the existence of the phenomenon of repositioning [21].

To summarize, using the case study methodology, the intention is not to test the theory, but rather to build a model [11], since the current theory does not emphasize the importance and the specifics of maritime port repositioning strategy in a holistic way.

\section{METHODOLOGY}

In this paper, the case study methodology has been applied [11-14]. A model of defining maritime port repositioning strategy will be developed by determining relationships between given propositions, which are supported by logical empirical arguments obtained by the analyses of the Port's functioning as an analytical unit [12-14]. The logic of defining propositions is that the repositioning strategy is actually the function of the answers/opinions which were received through the interviews with target respondents, and many corresponding (identical or similar) answers lead to a clearer strategy and concrete repositioning measures.

The answers/opinions were compared with the exact numerical values obtained from the completed questionnaires and the implementation of the Strategic Position and Action Evaluation (SPACE) matrix. It is emphasized that the SPACE matrix can be a helpful tool when choosing between four possible strategic options of repositioning: a) aggressive, b) competitive, c) defensive and d) conservative [22, 23]. According to the SPACE matrix, the selection of a particular repositioning strategy is influenced by the following matrix dimensions: a) competitive advantage (hereinafter: CA), b) industry strength (hereinafter: IS), c) financial strength (hereinafter: FS) and d) environmental stability (hereinafter: ES). The paper defines these dimensions as repositioning criteria.

The SPACE matrix is a four-quadrant framework, and there are seven steps necessary for its construction, as shown in Table 1 [24]:

Step 1: The selection of the variables for measuring $\mathrm{CA}$, IS, ES and FS.

Step 2: The evaluation of the variables by means of a dimension-specific rating system. The rating scale from -6 (the worst) to -1 (the best) is relevant for $\mathrm{CA}$ and $\mathrm{ES}$, while the rating scale from +1 (the worst) to +6 (the best) is relevant for IS and FS.

Step 3: The determination of the average scores for CA, IS, ES and FS.

Step 4: The plotting of the values obtained in Step 3 on the appropriate axis of the SPACE matrix.

Step 5: The indication of the final point on the $X$ axis - the addition of the average scores for the CA and IS dimensions.

Step 6: The indication of the final point on the $Y$ axis - the addition of the average scores for the SPACE matrix dimensions of ES and FS.

Step 7: The determination of the intersection between the $X$ and $Y$ points and the rendering of the line from the SPACE matrix center to the intersection, which will indicate the type of a recommendable strategy for the company.

The answer to the research question will be found by matching the information (data) collected through the primary research, which explored: a) different approaches that focused on the Port's present and potential markets and products, b) different methods of repositioning - the SPACE matrix and case study and 
Table 1 - The structure of the criteria for repositioning the Port

\begin{tabular}{|c|c|c|}
\hline & Internal criteria & External criteria \\
\hline & "Competitive advantage (CA) & Industry strength (IS) \\
\hline \multirow[t]{2}{*}{$x$} & (-6 worst, -1 best) & (+1 worst, +6 best) \\
\hline & 1. Market share & 1. Growth potential \\
\hline A & 2. Port services quality & 2. Industry profit potential \\
\hline$x$ & 3. Service product life cycle & 3. Industry flexibility/adaptability \\
\hline I & 4. Brand and image & 4. Capital intensity within the industry \\
\hline \multirow[t]{4}{*}{ S } & 5. Port customers loyalty & 5. Technological innovation and know-how \\
\hline & 6. Vertical integration in the supply chain & 6. Capacity utilization/ productivity \\
\hline & Total axis X score: CA average + IS average & \\
\hline & Financial strength (FS) & Environmental stability (ES) \\
\hline \multirow[t]{2}{*}{ Y } & (+1 worst, +6 best $)$ & (-6 worst, -1 best) \\
\hline & 1. Return on investment & 1. Technological changes in the environment \\
\hline A & 2. Liquidity & 2. Demand price elasticity \\
\hline$x$ & 3. Risk assessment & 3. Market entry barriers \\
\hline I & 4. Capital required/capital available & 4. Market competitiveness \\
\hline \multirow[t]{2}{*}{ S } & & $\begin{array}{l}\text { 5. Business risk (general economic conditions, GDP growth, } \\
\text { transport policy) }\end{array}$ \\
\hline & Total axis Y score: FS average + ES average & \\
\hline
\end{tabular}

c) different strategic options effective for concrete repositioning [25]. Finally, the model proposed is graphically presented at the end of the paper, and it clarifies the process of defining the maritime port repositioning strategy.

\subsection{Sample}

Since the aim of this research is to comply with the maritime port repositioning strategies using a holistic approach, the paper exploits the Triple Helix concept which is based on the combination of universityindustry-government relations [26]. Therefore, the following eight stakeholders were consulted:

a) Internal stakeholders:

- The representative of the Port Authority of Montenegro in Kotor - the General Manager

- Two representatives of the terminal operator Global Ports Holding

- Chief Executive Officer (hereinafter: CEO)

- Three top managers of the Port - the executives of the divisions for strategic marketing and sales, operations, finance and administration, and

b) External stakeholder:

- An academic expert on maritime transport and port operations from Faculty of Maritime Studies Kotor, the University of Montenegro.

A non-probability quota sample is used in the paper, which implies a clear definition of two basic groups of respondents (the abovementioned internal and external stakeholders) and a division of these groups according to the selected criteria into five subgroups or the so-called quotas. Each of the five quotas of respondents is included in the sample, regarding the hierarchical position which each respondent holds in their organization. In other words, the consulted stakeholders have the highest responsibility for managing the Port and their attitudes are listed correspondingly - the attitudes of the internal stakeholders precede those of the external stakeholders [27, 28].

We define the repositioning strategy through the research of four criteria (FS, CA, ES, IS), with each criterion having its attributes, which is twenty-one in total (as indicated in Table 1). Therefore, one hundred and sixty-eight quantitative and one hundred and sixty-eight qualitative answers were collected, which is three hundred and thirty-six answers in total. According to the case study methodology, one attribute for each criterion is discussed in detail (Tables 3-6).

\subsection{Data sources}

There were four data sources (Figure 2): (1) the initial CEO interview, (2) semi-structured interviews with each of the respondents, (3) questionnaires and (4) secondary sources $[12,13]$.

The CEO interview began by asking the CEO to describe the vision of the Port, its mission and actual competitive strategy. The CEO was then asked to describe the comparative and absolute advantages of the Port, recognize major competitors and their performance, major customers and the partners in the 


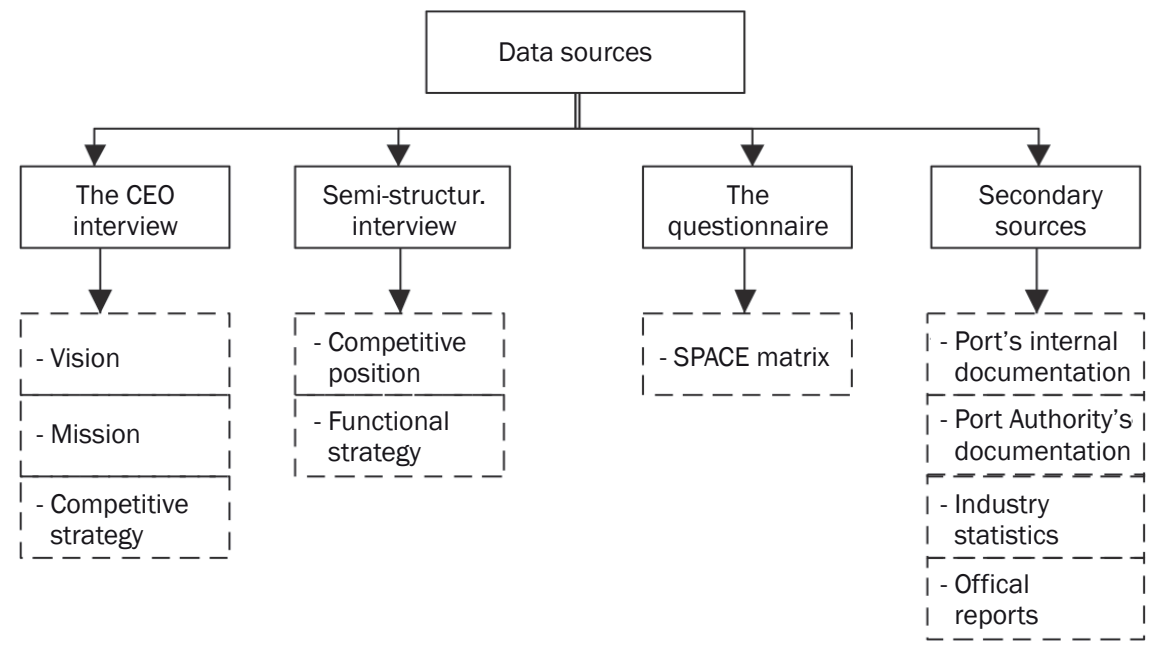

Figure 2 - Data sources

supply chain that involves the Port. The CEO then identified several recent or ongoing major plans and actual tactical measures to overcome the current situation, as well as the dynamics of implementation and their economic validity.

The semi-structured interviews with the top management team of the Port and the Global Ports Holding representatives were approximately 90 minutes long. The interview began with a request for a description of the actual competitive position of the company. Each executive then described the functional strategy of their area and personal opinion about the necessity of the repositioning process. Along these lines, we gained an insight into the framework of the specific repositioning criteria related to their department, as well as the specific tactics, approaches and dynamics of repositioning. Semi-structured interviews with the general manager of the Port Authority of Montenegro in Kotor and with an academic expert from the Faculty of Maritime Studies Kotor were identical to those previously described. We conceived questions focused on facts rather than the interpretations of respondents [11].

The questionnaire is structured in accordance with the SPACE matrix as an instrument for the valorization of strategic options [22, 23]. Table 1 shows the structure of the criteria for repositioning as follows: FS and CA are the internal criteria, IS and ES are the external criteria of repositioning. Each criterion has its own attributes, hence, we assume that: a) the number of attributes varies and it is possible to supplement/reduce it according to the circumstances of the market and the characteristics of the Port and b) from all of the attributes suggested in the literature, only those relevant for marketing are selected [29]. Regardless of different opinions in the literature, all criteria in this study were assigned equal relevance $[22,23]$.

In accordance with the explanation provided in Chapter 3, the respondents were asked to use specific numerical values and evaluate each of the four criteria analyzed. The evaluation scale is the following (Table 1): a) a scale ranging from 1 to 6 for FS and IS and $b$ ) a scale ranging from -1 to -6 for ES and CA. A 6-point Likert scale was used in order to impose the selection of a particular answer on a scale. It is commonly used when respondents have high expertise on a researched matter [30]. Based on the respondents' estimations, average values are calculated for all repositioning criteria and as such are used for defining the strategic option in the SPACE matrix (aggressive, competitive, defensive or conservative).

Secondary sources included the internal documentation of the Port and the internal documentation of the Montenegrin Port Authority, industry statistics and the official reports of the Government of Montenegro.

After summarizing the data collected from different sources, we proceeded with a formulation of propositions, as shown in tables in continuation.

\section{MODEL FOR DEFINING MARITIME PORT REPOSITIONING STRATEGY}

According to the responses collected through the questionnaires and interviews, presented in Table 2, we have defined five propositions and an overall repositioning strategy.

Proposition 1: A more precise estimation of the maritime port's financial strength leads to a clear definition of the repositioning strategy.

Cumulative results for financial strength as a criterion are satisfactory, even though the use of the Port's existing resources is evidently insufficient. This is confirmed by the average scores of respondents' estimated values for each of the attributes for repositioning, where: a) a return on investments is $3.750, b$ ) liquidity is 5.125, c) risk assessment is 3.125 and d) capital required/capital available is 3.375 (Table 2). It can be 
Šekularac-Ivošević S, Husić-Mehmedović M, Twrdy E. Repositioning Strategy in the Maritime Port Business: A Case Study from...

Table 2 - Evaluations of repositioning criteria

\begin{tabular}{|c|c|c|c|c|c|c|c|c|c|}
\hline Criteria/attributes & \multicolumn{9}{|c|}{ Respondents' evaluations (R1-R8) } \\
\hline Financial strength (FS) & R1 & R2 & R3 & $\mathrm{R} 4$ & R5 & R6 & R7 & R8 & Average \\
\hline 1. Return on invest. & 4 & 2 & 3 & 6 & 4 & 4 & 3 & 4 & 3.750 \\
\hline 2. Liquidity & 6 & 5 & 5 & 5 & 5 & 5 & 5 & 5 & 5.125 \\
\hline 3. Risk assessment & 3 & 2 & 2 & 6 & 3 & 3 & 2 & 4 & 3.125 \\
\hline 4. Capital req. /avail. & 2 & 2 & 3 & 4 & 4 & 5 & 2 & 5 & 3.375 \\
\hline & & & & & & & & & 3.844 \\
\hline Environmental stability (ES) & R1 & $\mathrm{R} 2$ & R3 & R4 & R5 & R6 & $\mathrm{R} 7$ & R8 & Average \\
\hline 1. Technol. change & -5 & -2 & -2 & -3 & -3 & -3 & -4 & -4 & -3.250 \\
\hline 2. Dem. price elastic. & -4 & -5 & -4 & -3 & -4 & -5 & -5 & -4 & -4.250 \\
\hline 3. Market entry barriers & -1 & -2 & -2 & -4 & -2 & -4 & -1 & -3 & -2.375 \\
\hline 4. Market competition & -5 & -6 & -4 & -6 & -5 & -3 & -6 & -5 & -5.000 \\
\hline 5. Business risk & -5 & -3 & -2 & -3 & -3 & -5 & -6 & -5 & -4.000 \\
\hline & & & & & & & & & -3.775 \\
\hline & & & & & & & is $Y$ & e: FS & $=0.069$ \\
\hline Competitive advantage (CA) & R1 & $\mathrm{R} 2$ & R3 & R4 & R5 & R6 & $\mathrm{R} 7$ & R8 & Average \\
\hline 1. Market share & -4 & -5 & -4 & -1 & -4 & -4 & -5 & -5 & -4.000 \\
\hline 2. Port serv. quality & -5 & -5 & -5 & -3 & -5 & -3 & -3 & -3 & -4.000 \\
\hline 3. Service prod. LC & -2 & -3 & -2 & -3 & -3 & -4 & -4 & -4 & -3.125 \\
\hline 4. Brand and image & -2 & -4 & -3 & -2 & -3 & -3 & -2 & -3 & -2.750 \\
\hline 5. Port customers loyalty & -3 & -2 & -2 & -2 & -2 & -2 & -2 & -4 & -2.375 \\
\hline 6. Vert. integr. in supply chain & -2 & -3 & -2 & -2 & -3 & -3 & -2 & -3 & -2.500 \\
\hline & & & & & & & & & -3.125 \\
\hline Industry strength (IS) & R1 & $\mathrm{R} 2$ & R3 & $\mathrm{R} 4$ & $\mathrm{R} 5$ & $\mathrm{R} 6$ & $\mathrm{R} 7$ & R8 & Average \\
\hline 1. Growth potential & 4 & 5 & 4 & 6 & 6 & 5 & 5 & 5 & 5.000 \\
\hline 2. Ind. profit potent. & 3 & 4 & 4 & 5 & 5 & 6 & 5 & 5 & 4.625 \\
\hline 3. Ind. flex. /adapt. & 4 & 4 & 4 & 5 & 6 & 6 & 6 & 6 & 5.125 \\
\hline 4. Capital intensity & 5 & 6 & 6 & 5 & 6 & 5 & 6 & 6 & 5.625 \\
\hline 5. Tech. innov. and know-how & 4 & 5 & 5 & 6 & 4 & 5 & 5 & 4 & 4.750 \\
\hline 6. Capacity util./ productivity & 5 & 5 & 4 & 5 & 4 & 4 & 6 & 4 & 4.625 \\
\hline & & & & & & & & & 4.958 \\
\hline
\end{tabular}

concluded that liquidity has a very high score, while the remaining attributes have a measure of central tendency and are very close to the average response.

Depending on the position that the respondents have, with respect to the specific operations of this Port, they differently evaluate individual attributes, which can be explained on the basis of the example of the capital required vs. capital available attribute (Table 3). In fact, representatives of the departments of finance, administration and operations find it necessary to buy a new crane, which, in their opinion, does not require significant additional capital with respect to the total available capital of the company.

A representative of the Port Authority of Montenegro believes that those capital investments are a priority that would enable the modernization of the transport infrastructure in the hinterland and that this would be a way to improve the existing position of the
Port in the market. Global Ports Holding representatives believe that significant additional capital, with respect to the available capital, is needed in order to implement a number of capital projects envisaged by the strategy for the development of the Port.

This fully corresponds to the fact that the Port has invested in the purchase of a new crane, the automation of the gate for storage, a new information system, modern electronic data interchange software, an increase in the number of plugs for reefer containers, which would affect the growth of the efficiency of container-handling operations per hour and better capacity utilization.

When it comes to the human resources policy, measures for a lay-off policy and for the motivation of highly qualified personnel have been taken, which will additionally improve liquidity and reduce financial risk in the business. 
Table 3 - Assessment of the Port's financial strength

\begin{tabular}{|c|c|c|}
\hline & Stakeholder & Example \\
\hline \multicolumn{3}{|c|}{ Particular attribute question: What is your opinion about capital required/capital available ratio? } \\
\hline \multirow{7}{*}{$\begin{array}{c}\text { Internal } \\
\text { stakeholders }\end{array}$} & $\begin{array}{l}\text { A representative of the Port } \\
\text { Authority of Montenegro }\end{array}$ & $\begin{array}{l}\text { "We are considering this question in a wider frame. Namely, the Port will be } \\
\text { better positioned if all the parties invest capital in the modernization of } \\
\text { transport infrastructure in the hinterland." }\end{array}$ \\
\hline & \multirow[t]{2}{*}{$\begin{array}{l}\text { Global Ports Holding } \\
\text { representatives }\end{array}$} & $\begin{array}{l}\text { "We need significant additional capital, with respect to the available capital, } \\
\text { in order to implement a number of capital projects envisaged by the } \\
\text { strategy of the Port development at the market of South-East Europe." }\end{array}$ \\
\hline & & "We need significant additional capital." \\
\hline & CEO & $\begin{array}{l}\text { "Realization of our mission is based on improvement of the ratio of required } \\
\text { capital vs. capital that is actually available." }\end{array}$ \\
\hline & \multirow{3}{*}{ Heads of departments } & $\begin{array}{l}\text { "Our department respects and shares the vision of the CEO and Global Port } \\
\text { Holding." }\end{array}$ \\
\hline & & $\begin{array}{l}\text { "The Port does not require significant additional capital with respect to the } \\
\text { total available capital." }\end{array}$ \\
\hline & & "Our situation is stable." \\
\hline $\begin{array}{c}\text { External } \\
\text { stakeholders }\end{array}$ & University expert & $\begin{array}{l}\text { "In environmental and technological sense, the Port environment is } \\
\text { constantly changing, so the Port needs more investment and additional } \\
\text { capital." }\end{array}$ \\
\hline
\end{tabular}

It can be concluded that the majority of respondents, i.e., six of them, clearly estimated that the Port needs to provide significant additional capital, in respect to that available, since the goal is to improve the current position of the Port in the market. Therefore, a repositioning of the product (the same target market/different product) is a recommendable repositioning approach here. The Port remains in the market of South-East Europe, but its repositioning is based on innovative service offers.

Proposition 2: A more precise estimation of the container port industry strength leads to a clear definition of the repositioning strategy.
The container port industry has a great potential in achieving long-term profits. The potential for growth in this industry has an average score of 5; the profit potential within the industry is 4.625; technological innovation and know-how is 4.750 , which really proves that it would be realistic to expect a larger number of customers in the Port even in the future (see Table 2).

Table 4 gives a brief overview of how the respondents had a unanimous attitude that the container port business has a remarkable potential to accumulate profits. By analyzing container port industry strength, some failures of business functioning can be noted. Namely, due to the high capital intensity within

Table 4 - The assessment of the container port industry strength

\begin{tabular}{|c|c|c|}
\hline & Stakeholder & Example \\
\hline \multicolumn{3}{|c|}{ Particular attribute question: What is your opinion about profit potential within the industry? } \\
\hline \multirow{7}{*}{$\begin{array}{c}\text { Internal } \\
\text { stakeholders }\end{array}$} & $\begin{array}{l}\text { A representative of the Port } \\
\text { Authority of Montenegro }\end{array}$ & $\begin{array}{l}\text { "It is necessary for Montenegro to have a successful container port that is a } \\
\text { serious competitor on the South-East European market. The Port of Adria is } \\
\text { the only one of this kind in Montenegro." }\end{array}$ \\
\hline & \multirow{2}{*}{$\begin{array}{l}\text { Global Ports Holding } \\
\text { representatives }\end{array}$} & $\begin{array}{l}\text { "One of the reasons why we invested in the Port is the profit potential within } \\
\text { the industry." }\end{array}$ \\
\hline & & $\begin{array}{l}\text { "The port in Antalya reported profit gain, which indicates that this industry } \\
\text { has a big potential. We believe that container business can be easier to } \\
\text { develop than any other business in the Port of Adria." }\end{array}$ \\
\hline & CEO & $\begin{array}{l}\text { "We are proud to manage the container part of the most important } \\
\text { Montenegrin maritime port system." }\end{array}$ \\
\hline & \multirow{3}{*}{ Heads of departments } & $\begin{array}{l}\text { "Our customers prefer container business. Furthermore, we see the chance } \\
\text { to increase profit in cruising business as well." }\end{array}$ \\
\hline & & "Our operations are primarily based on container cargo handling." \\
\hline & & "Our income is mostly derived from container operations." \\
\hline $\begin{array}{c}\text { External } \\
\text { stakeholders }\end{array}$ & University expert & "I evaluate this attribute with 6 (the highest score) and that says it all." \\
\hline
\end{tabular}


Table 5 - Example of the Port's competitive advantage assessment

\begin{tabular}{|c|c|c|}
\hline & Stakeholder & Example \\
\hline \multicolumn{3}{|c|}{ Particular attribute question: What is your opinion about your current market share? } \\
\hline \multirow{7}{*}{$\begin{array}{c}\text { Internal } \\
\text { stakeholders }\end{array}$} & $\begin{array}{l}\text { A representative of the Port } \\
\text { Authority of Montenegro }\end{array}$ & $\begin{array}{l}\text { "It is an internal matter of the Port management. We will take all the } \\
\text { measures to support them, because it is in the national interest to promote } \\
\text { this supply chain where Montenegro belongs." }\end{array}$ \\
\hline & \multirow{2}{*}{$\begin{array}{l}\text { Global Ports Holding } \\
\text { representatives }\end{array}$} & "It is our primary goal to increase the market share of the Port." \\
\hline & & "I found that our market share is smaller than our potentials are." \\
\hline & CEO & $\begin{array}{l}\text { "We are working on the application of the market share research methodol- } \\
\text { ogy. We find it a priority of the marketing department staff at the moment." }\end{array}$ \\
\hline & \multirow{3}{*}{ Heads of departments } & $\begin{array}{l}\text { "Our department employees are working on the implementation of the } \\
\text { Customer Relationship Management concept, due to the fact that we } \\
\text { already have customers, but we need more loyal relationships with them. } \\
\text { For that reason, our integrated marketing communication instruments have } \\
\text { been radically intensified." }\end{array}$ \\
\hline & & $\begin{array}{l}\text { "We have stabile clients, but in order to concur new ones we need higher } \\
\text { operations' efficiency and further development of the service offer." }\end{array}$ \\
\hline & & $\begin{array}{l}\text { "The income from container throughput is stable, or even higher in } \\
\text { comparison with the last year, but we still need to redirect cargo flows to } \\
\text { Bar rather than to other Adriatic ports." }\end{array}$ \\
\hline $\begin{array}{l}\text { External } \\
\text { stakeholders }\end{array}$ & University expert & "I evaluate this attribute as internal but understand it as a very important." \\
\hline
\end{tabular}

Table 6 - Example of the Port's environmental stability

\begin{tabular}{|c|c|c|}
\hline & Stakeholder & Example \\
\hline \multicolumn{3}{|c|}{ Particular attribute question: What is your opinion about your current business environment (risk)? } \\
\hline \multirow{7}{*}{$\begin{array}{c}\text { Internal } \\
\text { stakeholders }\end{array}$} & $\begin{array}{l}\text { A representative of the Port } \\
\text { Authority of Montenegro }\end{array}$ & $\begin{array}{l}\text { "We have the ambition to successfully implement the concession agree- } \\
\text { ment with the Turkish operator - Global Ports Holding. Public regulatory } \\
\text { bodies will give full support, as they will monitor the realization of these } \\
\text { objectives, especially due to the fact that the Port of Bar, as a unique } \\
\text { business system, was proclaimed a port of national importance." }\end{array}$ \\
\hline & \multirow{2}{*}{$\begin{array}{l}\text { Global Ports Holding } \\
\text { representatives }\end{array}$} & $\begin{array}{l}\text { "As any other foreign investor, we face difficulties which are direct conse- } \\
\text { quences of the fact that free market economy and institutions in Montene- } \\
\text { gro are yet to be developed. Global Ports Holding is a long-term partner. We } \\
\text { believe in Montenegrin institutions and that they obey positive legislation." }\end{array}$ \\
\hline & & $\begin{array}{l}\text { "Our vision is to provide a high-quality service in Bar and to match the } \\
\text { international standards in this sector which will lead to the local community } \\
\text { development by creating new opportunities. There are still many challeng- } \\
\text { es, but as long as we manage to solve the problems - we are satisfied." }\end{array}$ \\
\hline & CEO & $\begin{array}{l}\text { "Our internal and external environment needs positive boldness. This fact is } \\
\text { supported with the need for investments in order to strengthen our position } \\
\text { in the region and to include other partners from the business environment." }\end{array}$ \\
\hline & \multirow{3}{*}{ Heads of departments } & $\begin{array}{l}\text { "The intention is to provide favorable environment for achieving the } \\
\text { strategic objective: attracting the cruise business that would be capitalized } \\
\text { on the tourism potential of the coastal region of Montenegro." }\end{array}$ \\
\hline & & "General conditions for business could be improved." \\
\hline & & "We found our environment very stimulating for investors." \\
\hline $\begin{array}{c}\text { External } \\
\text { stakeholders }\end{array}$ & University expert & "I evaluate the exposure to business risk as neither low nor high." \\
\hline
\end{tabular}


the industry, successful container ports maintain good productivity and operational efficiency, which is not the practice in this Port. According to data from the operations department, the available resources are currently used at about $40 \%$ of their capacity in general, which is not sufficient, considering that the estimated capacity for general cargo throughput is 6 million tons and for containers 750,000 TEU.

The general conclusion is that the container port industry is among the most profitable ones in maritime affairs and this Port must improve the following two attributes: (1) technological innovation and know-how and (2) productivity/capacity utilization. A transition into alternative branches of the industry is not recommended. Rather, the available competitive advantages in the present market should be strengthened.

Proposition 3: A more precise assessment of the maritime port's competitive advantage leads to a clear definition of the repositioning strategy.

Table 5 presents that the majority of respondents share the opinion that the current market share of the Port needs to be increased. The respondents agreed that the Port's current market share is rather weak and unstable (-4). Furthermore, they did not give high rating to the quality of service $(-4)$, but the very important thing from the point of marketing is that the partnerships with external stakeholders are at a satisfactory level, especially customer loyalty and vertical integration in the logistic route which includes the Port (see Table 2).

The heads of departments believe that the Port has a significant number of loyal customers. However, what troubles the marketing department is a drain of potential customers and a decrease in the number of major customers. On the other hand, it is very encouraging that the leading brands in shipping, MSC and CMA CGM, have their representative offices in Bar. Furthermore, the Port opened a representative office in Belgrade in December 2016, which means that the impulse from the market is favorable for the future competitive performance of this Port. It is clear that the integrated marketing communications have been improving in order to increase a share in the market of South-East Europe. In doing so, the Port uses the same market/different product repositioning approach.

Proposition 4: A more precise assessment of the environmental stability leads to a clear definition of the repositioning strategy.

The business environment of the Port is relatively stable. Namely, the respondents state the following: the competition is very strong $(-5)$, there is a considerable business risk (-4), demand is quite flexible regarding the price policy $(-4.250)$, there are minor technological changes (-3.250) and entry barriers to the market are stimulating for investors (-2.375) (see Tables 2 and 6).
Table 6 presents a qualitative assessment of the current business environment and potential risks. Respondents perceive the business environment of the Port to be at a certain level of risk, primarily in terms of the development of the market economy and institutions in Montenegro. This opinion corresponds to a rate of (-4), meaning that the business environment of the Port also ought to be improved. The Port stimulates the development of the local and national community, especially by investing in Montenegro as a cruise destination. In 2016, seven cruise ships and 8,660 tourists arrived at the Port, which means that the Port improves its offer by using the same market/different product approach. Radical measures are needed in order to lead the community, which is best confirmed by the statement of the Port's CEO (Table 6).

Proposition 5: Matching different approaches, alternative methods and strategic options leads to a simpler definition of the unique repositioning strategy of the maritime port.

In order to support Proposition 5 by using the SPACE matrix, we have analyzed four strategic options: aggressive, competitive, defensive and conservative. The SPACE matrix results are presented in the coordinate system based on the values of previously examined repositioning criteria (as shown in Figure 3).

The research results lead to the following conclusions:

a) The first coordinate value (1.833) is the sum of the average values for competitive advantage (CA) and container port industry strength (IS), while the second coordinate value (0.069) is the sum of the average values for financial strength (FS) and environmental stability (ES). This means that an aggressive type of repositioning strategy is recommendable for this Port (Figure 3). Generally, this type of strategy requires the usage of internal strengths to develop market penetration and market development strategy, which can include product development and integration with other companies and, above all, competitors in the logistic chain. This means that the Port needs to build the existing market share and actual competitive advantages by aggressively using the available market opportunities and the optimal allocation and coordination of internal resources. This strategy also includes constant monitoring of all business steps taken by the competing ports in order to proactively develop alternative competitive advantages. Economic logic explains how the Port obtains the returns when implementing the strategy. In this specific case it can be achieved by cost reduction, which includes the improvement of efficiency in the execution of handling operations and the optimal utilization of capacity that will ensure regular and profitable cargo flows at the Port. 


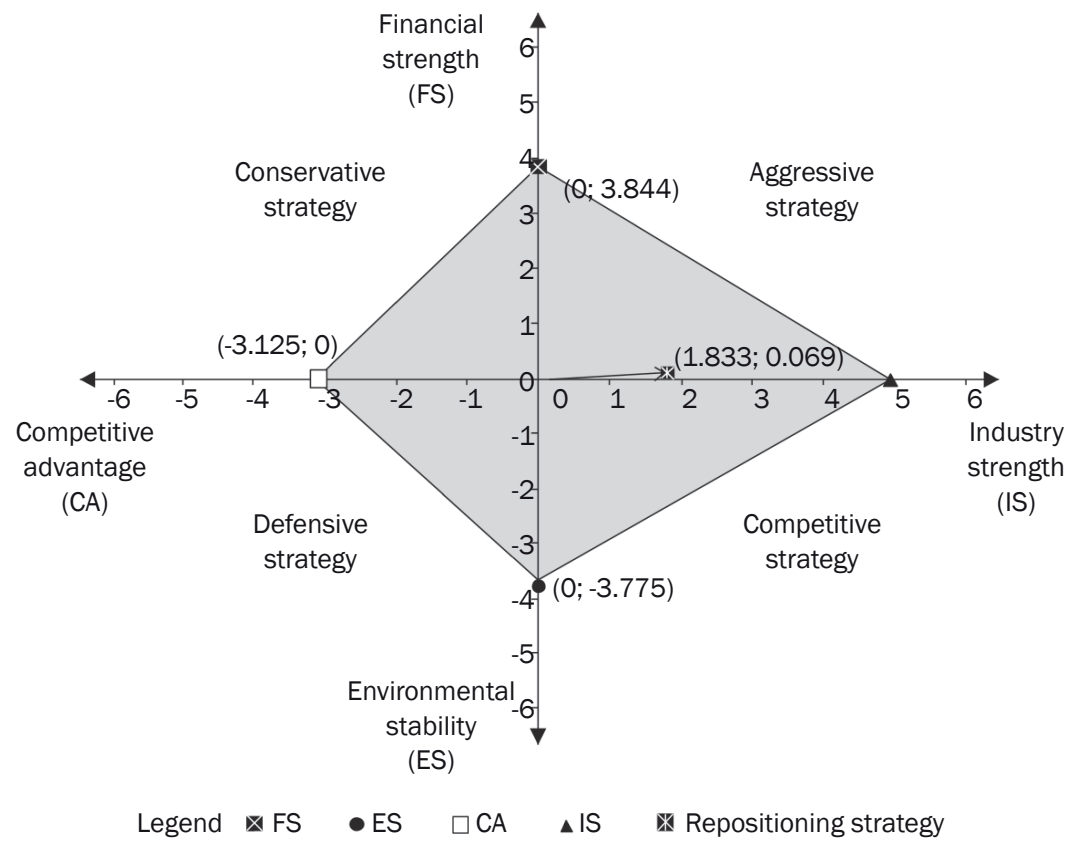

Figure 3 - Repositioning strategy chart of the Port

b) Criteria such as competitive advantage (CA), environmental stability (ES) and financial strength (FS) show weaknesses in relation to the container port industry strength (IS), which principally confirms that it is necessary to strengthen the current position of the Port. The financial strength (FS) and environmental stability (ES) are, on average, identically evaluated, which means that no matter how great the competitive pressure is, the management can (slightly) withstand the environmental challenges. This is confirmed by the average values of the repositioning criteria analyzed, which are as follows: a) $\mathrm{CA}=-3.125$, b) IS=4.958, c) $\mathrm{FS}=3.844$ and d) $E S=-3.775$ (Figure 3).

c) The repositioning strategy of the Port is based on the same market/different product approach which implies that the Port should stay in the existing market of the South-East Europe, while the

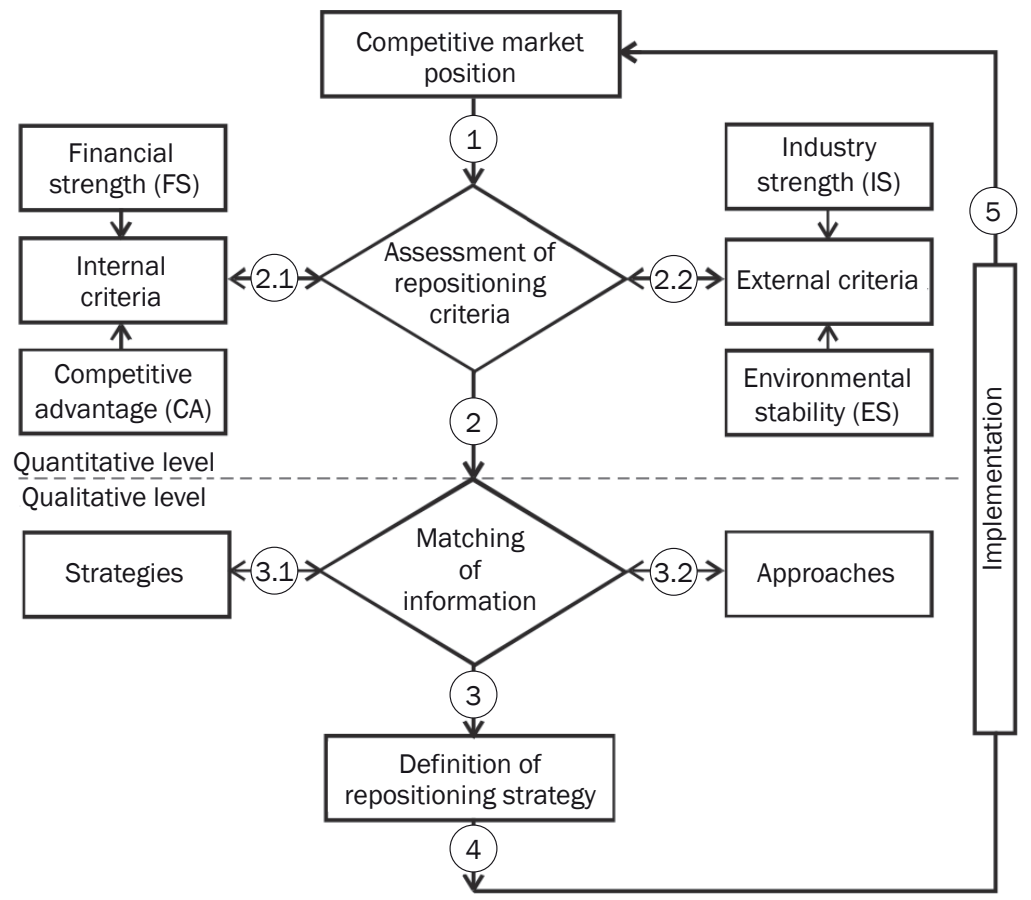

Figure 4 - The model for defining a maritime port repositioning strategy 
crucial aspect of the strategy is the differentiation of the existing service product. This implies the creation of a vast array of services that would, in comparison with the competition, be more valuable for the customers. Herewith, the model of defining the repositioning strategy of maritime ports can be graphically presented (Figure 4).

The model consists of quantitative and qualitative levels of the analysis of the available data obtained through primary research.

The quantitative level of analysis is initiated by setting a goal. The goal of the research is a competitive market position 1, which can and has to be achieved by the implementation of an efficient repositioning strategy. The desired competitive position is determined by the quality and the potential of the internal (2.1) and external (2.2) repositioning criteria. The value of the criteria is assessed by representative stakeholders. The numerical results of the assessment (2) are summarized in the quantitative expression (Table 2), while the qualitative results are summarized according to Tables 3-6.

The second level of the model is the qualitative level of the analysis which defines the repositioning strategy (4). The process known as matching information is of the utmost importance for the repositioning strategy (3). The defined strategy is obtained through the combination of repositioning strategic options (3.1) and approaches to repositioning (3.2). Those strategic options are achieved by the application of the SPACE matrix (as illustrated in Figure 3), while the approaches to repositioning are established through the use of the case study method and the harmonization of the respondents' attitudes.

\section{CONCLUSIONS}

It is argued at the beginning of this paper that total cargo throughput and other business performances of the Port of Adria were considered weak in comparison with the competition. The strategy, therefore, emerged out of the need for improvement of the existing position of the Port of Adria. The findings presented suggest that contemporary maritime ports should constantly explore their financial and environmental stability, competitive advantage and industry strength in order to be alert enough to reposition on time.

The research raises an important question about the manner in which the maritime ports in the highly competitive maritime port industry define optimal repositioning strategies for achieving competitive advantages and better market positions. This paper defines: a) the type of repositioning strategy, b) a concrete strategic option based on the capacity of four criteria for repositioning, and c) a market approach to repositioning. In addition, the paper defines the model which highlights the synergistic effect of the application of two different tools in solving the problem of maritime port repositioning, as well as the multiple-perspective analysis of the maritime ports.

It was found that the attitudes of internal and external stakeholders represent a solid base for the repositioning of maritime ports. This is important for university-industry-government relations, because it reveals the key stakeholders in maritime port business and the criteria by which they can be included in the research. As a result of the research, the relationships of trust between the respondents and the researchers are considered necessary, since the interviews conducted were of an in-depth type.

This paper contributes not only to the solution of the marketing problem of repositioning, but to strategic decision-making within the maritime port management as well. If policy makers were to implement the results of this study, they might achieve: a) innovations of the service product, b) marketing rebranding of the Port of Adria as a vital factor in the local community and an important maritime port in the South-East Europe market, c) horizontal integration with competing maritime ports and d) vertical integration with major economic and industrial partners in the market. Additionally, the paper is a practical contribution to the development of marketing as a business function of maritime ports.

It would be fruitful to pursue further research in several directions. Stakeholders' opinion on maritime port development is of crucial importance once setting a new development strategy. In that sense, one of the research directions should include providing more external stakeholders opinions in creating a repositioning strategy. In this process, perceptions of internal and external repositioning criteria by the Port of Adria competing ports are especially important because they achieve faster development. The assessment of the maritime port growth in terms of net profit, revenue, sales or increased market share with the aim of exploiting market opportunities is another possible direction of further research. This means that the paper could contribute to the investigation of relations between the results of the repositioning strategy implemented and the aforementioned parameters of business growth.

Dr SENKA ŠEKULARAC-IVOŠEVIĆ, docent ${ }^{1}$

E-mail: senkas@ucg.ac.me

Dr MELIKA HUSIĆ-MEHMEDOVIĆ, profesor ${ }^{2}$

E-mail: melika.husic@efsa.unsa.ba

Dr ELEN TWRDY, redovni profesor ${ }^{3}$

E-mail: elen.twrdy@fpp.uni-lj.si

1 Univerzitet Crne Gore, Pomorski fakultet Kotor Dobrota 36, 85330 Kotor, Crna Gora

2 Ekonomski fakultet u Sarajevu

Trg oslobođenja - Alija Izetbegović 1, 71000 Sarajevo, Bosna i Hercegovina

${ }^{3}$ Univerzitet u Ljubljani, Fakultet za pomorstvo i promet 
Pot pomorščakov 4, 6320 Portorož, Slovenija

\section{STRATEGIJA REPOZICIONIRANJA U POSLOVANJU MORSKIH LUKA: STUDIJA SLUČAJA CRNE GORE, PORT OF ADRIA}

\section{SAŽETAK}

Osnovni cilj ovog rada je definisanje strategije repozicioniranja Port of Adria-e koja je vodeća kontejnerska morska luka Crne Gore. Strategija je integralni odraz analize internih (konkurentska prednost i finansijska snaga) i eksternih (potencijal industrije kontejnerskih morskih luka i stabilnost okruženja) kriterijuma repozicioniranja. Studija slučaja u ovom radu većinski se ostvaruje kroz definiciju specifičnih propozicija koje razjašnjavaju veze između navedenih kriterijuma i strategije repozicioniranja. Znanje i stavovi stejkholdera se koriste u svrhu modeliranja marketinške strategije koja se zasniva na induktivnoj studiji. Rad predlaže model zasnovan na specifičnom slučaju morske luke, a koji se takođe može primijeniti na bilo koji drugi slučaj repozicioniranja morskih luka.

\section{KLUČNNE RIJEČI}

repozicioniranje morske luke; finansijska i stabilnost okruženja; konkurentska prednost; kontejnerska industrija; SPACE matrica;

\section{REFERENCES}

[1] Cahoon SC, Hecker R. Seaports in the New Economy: using services marketing strategies to increase cargo throughput in a hypercompetitive environment. In: IAME Proceedings of the International Association of Maritime Economists Conference (IAME), 23-25 June, Limassol, Cyprus; 2005. p. 1-22.

[2] Flynn M, Lee PTW, Notteboom T. The Next Step on the Port Generations Ladder: Customer-Centric and Community Ports. In: Notteboom, T. (ed.) Current Issues in Shipping, Ports and Logistics. Brussels, Switzerland: Academic and Scientific Publishers; 2011. p. 497-510.

[3] Notteboom T. The relationship between seaports and the intermodal hinterland in light of global supply chains. OECD International Transport Forum, 10-11 April 2008. (Discussion Paper 2008-10). Available from: http://www.oecd-ilibrary.org/docserver/download/235371341338. pdf?expires $=1512928287 \& i$ $\mathrm{d}=\mathrm{id} \&$ accname $=$ guest\&checksum $=0 \mathrm{D} 41 \mathrm{FA90ECD}$ D71A932EFF5015C508AFB [Accessed $10^{\text {th }}$ November 2017].

[4] Hooley G, Saunders JA, Piercy NF. Marketing Strategy $\&$ Competitive Positioning. $4^{\text {th }}$ edition. Harlow: Financial Times-Prentice Hall; 2008.

[5] Kotler P, Keller K. Marketing Management. $12^{\text {th }}$ edition. New Jersey: Pearson Education Inc.; 2006.

[6] Kaikati J. Lessons From Accenture‘s 3Rs: Rebranding, Restructuring, and Repositioning. Journal of Product and Brand Management. 2003;12(7): 477-490. Available from: http://www.scribd.com/doc/101843361/ Lessons-From-Accenture-s-3Rs-Rebranding-Restructuring-and-Repositioning [Accessed $10^{\text {th }}$ October 2012].
[7] Port of Adria. Available from: http://www.portofadria. me/ [Accessed 5 January 2016].

[8] Port Authority of Montenegro. Available from: http:// www.luckauprava.gov.me/direktor/o_nama [Accessed 5 January 2016].

[9] Bauk S, Šekularac-Ivošević S, Jolić N. Seaport Positioning Supported by some Quantitative and Qualitative Approaches. Transport. 2015;30(4): 385-396.

[10] Šekularac-Ivošević S, Bauk S, Gligorijević M. Combining the concepts of benchmarking and matrix game in marketing (re)positioning of seaports. Promet - Traffic \& Transportation. 2013;25(5): 431-443.

[11] Eisenhardt KM, Graebner ME. Theory building from cases: Opportunities and challenges. Academy of Management Journal. 2007;50(1): 25-32.

[12] Eisenhardt KM. Building Theories from Case Study Research. The Academy of Management Review. 1989b;14(4): 532-550.

[13] Eisenhardt KM. Making fast strategic decisions in high-velocity environments. Academy of Management Journal. 1989a;32(3): 543-576.

[14] Yin RK. The Case Study Crisis: Some Answer. Administrative Science Quarterly. 1981;26(1): 58-65.

[15] Turner C. Issues and challenges in strategic repositioning: the case of Cable and Wireless. Strategic Change. 2003;12(5): 251-257.

[16] Corstjens M, Doyle P. Evaluating Alternative Retail Repositioning Strategies. Marketing Science. 1989;8(2): 170-180.

[17] Pardali A, Michalopoulos V. Determining the position of container handling ports, using the benchmarking analysis: the case of the Port of Piraeus. Maritime Policy \& Management. 2008;35(3): 271-284.

[18] Milisavljević M. Strategijski marketing. Beograd: Centar za izdavačku delatnost Ekonomskog fakulteta; 2006.

[19] Hatch M, Schultz M. Bringing the Corporation into Corporate Branding. European Journal of Marketing. 2003;37(7/8): 1041-1064. Available from: http:// www.livingthebrand.com/upload/Corporate $\% 20$ Branding.pdf [Accessed 10 October 2012].

[20] Yin RK. Case study research: Design and methods. $2^{\text {nd }}$ edition. Newbury Park, CA: Sage; 1994.

[21] Dutton JE, Dukerich JM. Keeping an eye on the mirror: The role of image and identity in organizational adaptation. Academy of Management Journal. 1991;34(3): 517-554.

[22] Ghochani MG, Kazami F, Alavije MA. Application of SPACE Matrix. Developing Country Studies. 2012;2(8): 50-59.

[23] Radder L, Louw L. The SPACE matrix: a Tool for Calibrating Competition. Long Range Planning. 1998;31(4): 549-559.

[24] Maxi-pedia. SPACE matrix Strategic Management Method. Available from: http://www.maxi-edia.com/ space+matrix+model+strategic+management+method [Accessed 11 November 2017].

[25] David FR. Strategic Management. $8^{\text {th }}$ edition. New Jersey: Prentice Hall; 2001.

[26] Etzkowitz $\mathrm{H}$. Innovation in innovation: The triple helix of university-industry-government relations. Social Science Information. 2003;42(3): 293-337.

[27] Azevedo SG, Pires da Cruz MR, Ferreira JJ. Key factors 
of seaport competitiveness based on the stakeholder perspective: An Analytic Hierarchy Process (AHP) model. Maritime Economics \& Logistics. 2013;15(4): 416-443.

[28] Notteboom T, Winkelmans W. Stakeholder relations management in ports: Dealing with the interplay of forces among stakeholders in a changing competitive environment. Paper presented at: International Association of Maritime Economists Conference (IAME),
13-15 November, Panama City, Panama; 2002.

[29] Krstić B. SPACE matrix - Strategic Management tool for Identification Strategic Position of Enterprise. Strategic Management. 2001;5(2): 53-58.

[30] Pradeep P. Basics of Likert. Health Services \& Outcomes Research. 2010;2010/5. Available from: https://hsor.nhg.com.sg/publications/newsletters/ NewslettersDocLibrary/issue-14.pdf $\left[\right.$ Accessed $12^{\text {th }}$ November 2017]. 